\title{
Workers Laying Off Policy as an Impact of the Covid-19 Pandemic
}

\author{
Conie Pania Putri \\ UKB Palembang University, 02177716380 \\ \{coniepania79@gmail.com\}
}

\begin{abstract}
Basically, entrepreneurs, workers/laborers, trade/labor unions, and the government must make every effort to prevent termination of employment. However, legal issue arises over the policy of laying off workers where workers do not do work, so whether their right to receive wages is still fully paid, partially paid, or not paid at all. Several employers implementing a policy of laying off their workers to suppress and reduce company operating expenses because the company does not get income due to discontinued business activities or production. However, legal issues arise over the policy of laying off workers where workers do not do work, so whether their right to wages are still paid in full, partially paid, or not paid at all. The research method is juridicalnormative legal research. The conclusion of this study is in accordance with Article 93 paragraph (2) Juncto Article 186 paragraph (1) of the Manpower Law, states that employers are obliged to pay wages if the worker/laborer is willing to do the work that has been promised but the employer does not employ him. The amount of wages received can still be negotiated with the trade/labor unions and/or workers/laborers based on the Minister of Manpower's Circular No. SE-05/M/BW/1998.
\end{abstract}

Keywords: Covid-19 Pandemic; Employment Laying off Policy; Wage Arrangement

\section{Introduction}

Human rights are basic human rights that exist and are a gift from God the Almighty. In addition, human rights are also natural rights, and therefore cannot be revoked by other human beings. Human rights are defined as rights inherent in the dignity of humans as creatures created by God and these rights are subordinate to humans from birth to the face of the earth so that these rights are innate (natural) and are not a gift from humans or the state [1]. Human rights are believed to have universal values, which means they do not recognize the boundaries of time and space [2]. Human rights in Indonesian national law are regulated in several laws and regulations, one of which is Law Number 39 of 1999 concerning Human Rights, which states that Human Rights are a set of rights inherent in the nature and existence of humans as creatures created by God Almighty and are His gifts that must be respected, upheld and protected by the rule of law, the Government, and everyone for the honor and 
protection of human dignity (Article 1 point 1 of Law Number 39 of 1999 concerning Human Rights).

In the implementation of business activities, it is necessary to have the role of Manpower in the continuity of the business world, for this reason Manpower needs to be protected by their rights. The objective of legal protection for labor is to guarantee basic rights of workers and ensure equality and treatment without discrimination on any basis to realize the welfare of workers and their families while still paying attention to the progress of the business world and the interests of employers [3]. The basic rights of workers as well as the rights of citizens are always guaranteed and upheld in the 1945 Constitution of the Republic of Indonesia in terms of Human Rights.

Based on Article 28D paragraph (1) of the 1945 Constitution of the Republic of Indonesia it is mandated that "everyone has the right to recognition, guarantee, protection and legal certainty that is just and equal treatment before the law", the principles contained in that article are that all Indonesian citizens have an equal position in the law and their rights must be upheld in the law. More specifically for Workers, that it is the right for every citizen to work and a decent living as stipulated in Article 27 paragraph (2) of the 1945 Constitution of the Republic of Indonesia that "Every citizen has the right to work. and a decent living for humanity." Based on the article, the right of every citizen to work and a decent living is one of the human rights that must be upheld by all parties in the life of the nation and state, so that the State should guarantee the rights of citizens who work.

The Covid-19 pandemic, which is currently spreading throughout the world, with no exception in Indonesia, had a serious impact both on health and on the economy. The Covid19 pandemic resulted in decreased company productivity, even in several business sectors such as the hotel sector, transportation, retail, restaurants and other sectors were forced to stop their business activities. This certainly has an impact on the work relationship between employers and workers where employers find it difficult to pay workers salaries.

Basically, entrepreneurs, workers/laborers, trade/labor unions, and the government must make every effort to prevent termination of employment (Article 151 paragraph (1) of Law Number 13 Year 2003 concerning Manpower), therefore several employers do not give their workers a choice by implementing a policy of laying off their workers to suppress and reduce company operating expenses from paying employee salaries because the company does not get income due to discontinued business activities or production. However, legal issues arise over the policy of laying off workers where workers do not do work, so whether their wages are still paid in full, partially paid, or not at all.

The policy of laying off employees in the midst of the Covid-19 pandemic is considered to be more beneficial to companies and detrimental to workers where many employers do not pay salaries for workers who are laying off, but the employer also does not terminate the employment relationship because if the employer terminates the employment relationship, the employer is obliged to provide compensation to workers in the form of severance pay, period of service pay, and compensation for rights in accordance with the provisions of Law Number 13 of 2003 concerning Manpower.

The research method used in this research is juridical-normative legal research, with library material which includes primary legal materials, namely the Constitution of the Republic of Indonesia Year 1945, Law Number 13 Year 2003 concerning Manpower, Presidential Decree Number 12 Year 2020 concerning Disaster Determination. Non-Natural Spread of Corona Virus Disease 2019 (Covid-19) As a National Disaster, Minister of Manpower Circular Number M/3/HK.04/III/2020 of 2020 concerning Protection of Workers/Laborers and Business Continuity in the Context of Prevention and Overcoming 
COVID-19, and the Minister of Manpower Circular No. SE-05/M/BW/1998 of 1998 concerning Wages of Workers Who Are Homeed Not Towards Termination of Employment, then secondary legal materials which include previous legal research, legal books, scientific journals, and other legal materials, then finally the tertiary legal material, namely Kamus Besar Bahasa Indonesia.

This research has 2 (two) problem formulations, namely:

a. How is the regulation of wages for laying off workers?

b. What is the legal protection for workers who are laying off but do not receive a salary?

\section{Analysis and Discussion}

\subsection{Regulation of Wages for Laying Off Workers}

The relationship that occurs between Workers and Employers is a work relationship where Article 50 of Law Number 13 Year 2003 concerning Manpower states that the work relationship occurs because of a work agreement between the entrepreneur and the worker / laborer. The work agreement only ends when things occur as regulated in Article 81 number 16 Law Number 11 of 2020 concerning Job Creation which amends Article 61 paragraph (1) of Law Number 13 of 2003 concerning Manpower, namely if the Worker death, the end of the work agreement period, the completion of a certain job, a court decision and / or an industrial relations dispute settlement institution that has permanent legal force, or certain circumstances or events that are stated in the work agreement, company regulations, or agreements joint work which can lead to the termination of the working relationship, therefore the worker who is sent home still has the status of a worker in the company.

Based on 1 number 1 Government Regulation Number 78 of 2015 concerning Wages, it is stated that Wages are the rights of workers / laborers that are received and expressed in the form of money as compensation from employers or employers to workers / laborers who are determined and paid according to an employment agreement, agreement, or laws and regulations, including allowances for workers / laborers and their families for a job and / or service that has been or will be performed.

Discussing the arrangement of wages given to workers who are laid off can refer to the Circular of the Minister of Manpower No. SE-05 / M / BW / 1998 Year 1998 concerning Wages of Workers Who Are Homeed Not in the Direction of Termination of Employment, which in the regulation confirms the rights of workers who are sent home to wages, with the following conditions:

a. Entrepreneurs continue to pay wages in full, namely in the form of basic wages and fixed allowances while the workers are laid off, unless otherwise stipulated in the work agreement, company regulations or collective working agreement.

b. If the employer is going to pay the worker's wages not in full, then it is necessary to negotiate with the worker's union and / or workers regarding the amount of wages during the stay and the length of time they are sent home.

The worker who is sent home still has the status of a worker and is still bound by a working relationship, the worker is still entitled to his rights as a worker, including one of which is wages in accordance with the provisions in Article 81 point 25 of Law Number 11 of 2020 concerning Copyright Work, which contains only Article 88A paragraph (1) of Law Number 11 of 2020 concerning Job Creation, which regulates that workers' rights to wages 
arise when a work relationship occurs between the worker and the entrepreneur and ends when the employment relationship is terminated.

In response to the Covid-19 Pandemic, on March 17, 2020 a Circular of the Minister of Manpower Number M/3/HK.04/III/2020 of 2020 concerning Protection of Workers / Laborers and Business Continuity in the Context of Prevention and Overcoming of COVID-19 This regulation can be used as a reference by employers in providing wages to employees who are laid off, where this regulation was issued in connection with the increasing spread of COVID19 in several regions of Indonesia and taking into account the official statement of the World Health Organization (WHO) which declared COVID-19 a global pandemic.

In Point II of the Minister of Manpower Circular Number M/3/HK.04/III/2020 of 2020 concerning Protection of Workers / Laborers and Business Continuity in the Context of Prevention and Overcoming of COVID-19, it is stated that the wage protection scheme for workers/laborers related to the Covid pandemic -19, can be described as follows:

a. For workers/laborers who are categorized as People Under Monitoring (ODP) COVID-19 based on a doctor's statement so that they cannot come to work for a maximum of 14 days or according to Ministry of Health standards, their wages are paid in full.

b. For workers/laborers who are categorized as suspected cases of COVID-19 and are quarantined/isolated according to a doctor's statement, their wages are paid in full during the quarantine/isolation period.

c. For workers/laborers who do not come to work because they are sick with COVID-19 and it is proven by a doctor's statement, the wages are paid according to statutory regulations.

d. For companies that limit their business activities as a result of government policies in their respective regions for the prevention and control of COVID-19, causing some or all of their workers/laborers not to come to work, taking into account business continuity, changes in the amount and method of payment of worker / labor wages are made. according to the agreement between the entrepreneur and the worker / laborer.

Responding to the Covid-19 Pandemic, and based on the aforementioned provisions also taking into account business continuity, changes in the amount and method of payment of workers' wages subject to the policy of laying off employees are carried out in accordance with the agreement between employers and workers.

\subsection{Legal Protection for Workers Who are Laying Off but Do Not Receive a Salary}

Legal protection arises because of a legal relationship. Legal relations are interactions between legal subjects that have legal relevance or have legal consequences (the emergence of rights and obligations) [4]. Legal protection according to the definition of Satjipto Raharjo is to provide protection to human rights that have been harmed by others and this protection is given to the community so that they can enjoy all the rights provided by law [5]. Law is directed entirely as a means to support development, whereas what should be development is only a means to increase human dignity, so it is clear that by law we will create or create prosperity for society [6].

Legal protection in English is called legal protection, while in Dutch it is called Rechtsbechermin. Harjono gives the definition of legal protection as protection by using legal means or protection provided by law, aimed at protecting certain interests, namely by making the protected interest into a legal right [7]. Legal protection is an effort to protect someone's interests by giving that person power to take actions that fulfill their interests [8].

The aim of legal protection for workers is to guarantee basic rights of workers and to ensure equality and treatment without discrimination on any basis to realize the welfare of 
workers and their families while still paying attention to the progress of the business world and the interests of entrepreneurs [9]. Therefore, Law Number 13 of 2003 concerning Manpower was formed which further regulates the provisions of employment. The objectives of manpower development according to Article 4 of Law Number 13 Year 2003 concerning Manpower are as follows: empowering and empowering manpower in an optimal and humane manner; realizing equal employment opportunities and providing manpower in accordance with the needs of regional national development; provide protection to workers in realizing welfare; and improve the welfare of workers and their families.

In essence, the position of workers can be viewed from two aspects, namely from a juridical and socio-economic perspective. From a juridical perspective, the position of a worker / laborer based on the provisions of Article 27 of the 1945 Constitution is the same as that of an entrepreneur or employer. In fact, socially and economically the position between workers and employers is higher than workers [10].

This imbalance between workers and employers is because there are those who think that employers are the owners of the company, so that any activity depends on the will of the entrepreneur. This situation creates a tendency for employers to act arbitrarily against workers. So, there needs to be intervention from the government to provide legal protection. Legal protection according to Philipus M. Hadjon, namely: "Always related to power. There are two powers that are always a concern, namely government power and economic power. In terms of government power, the issue of legal protection for the people (who are governed), against the government (who govern). In terms of economic power, the issue of legal protection is protection for the weak (economy) against the strong (economy), for example protection for workers against employers." [11]

Law Number 13 of 2003 concerning Manpower states that protection of workers is intended to guarantee basic rights of workers / labor and guarantee equal opportunity, as well as treatment without discrimination on any basis to realize the welfare of workers / laborers and their families while still paying attention to developments in world progress. effort.

Based on Article 93 paragraph (1) of Law Number 13 of 2003 concerning Manpower, which states that wages are not paid if the worker/laborer does not perform work. In addition, there are also exceptions for workers who do not perform work but due to reasons contained in Article 93 paragraph (2) of Law Number 13 Year 2003 concerning Manpower.

As discussed in the previous chapter, if there are Employers who do not pay wages to Workers who are subject to the policy of laying off employees, or if there are Workers who do not get their rights in full according to the agreement made between employers and workers, then based on Article 95 paragraph (2) Law Number 13 of 2003 concerning Manpower, the entrepreneur may be subject to fines. The provisions for fines are regulated in Article 55 paragraph (1) of Government Regulation Number 78 of 2015 concerning Wages, which stipulates that Entrepreneurs who are late in paying and/or not paying wages are subject to fines, provided that:

a. Starting from the fourth day to the eighth day from the date the Wages should be paid, a fine of $5 \%$ (five percent) is imposed for each day of delay of the Wages that should have been paid;

b. after the eighth day, if the Wages are still not paid, the late fees as referred to in letter a shall be imposed plus $1 \%$ (one percent) for each day of delay provided that 1 (one) month cannot exceed $50 \%$ (fifty percent) of the Wages. that should be paid; and

c. after a month, if the Wages are still not paid, a penalty for late payment as referred to in letter $\mathrm{a}$ and letter $\mathrm{b}$ shall be imposed plus interest equal to the interest rate applicable to the state bank. 
The imposition of fines as referred to in these articles should not eliminate the obligation of employers to continue to pay Wages to Workers / Laborers based on Article 55 paragraph (2) of Government Regulation Number 78 of 2015 concerning Wages.

Workers can take legal remedies to resolve these legal problems as regulated in Law No. 2 of 2004 concerning the Settlement of Labor Disputes, in which the basis for disputes between Workers and Employers is a dispute over rights, as regulated in Article 1 paragraph (2) in Law No. 2 of 2004 concerning the Settlement of Labor Disputes, that disputes over rights are disputes that arise because rights are not fulfilled, due to differences in the implementation or interpretation of the provisions of laws and regulations, work agreements, company regulations, or collective labor agreements.

In Law Number 2 of 2004 , it is possible to settle industrial relations disputes through juridical (litigation) and non-juridical (non-litigation) channels. Dispute settlement through the Industrial Relations Court is carried out as a last resort if the bipartite or tripartite settlement is declared unsuccessful. Settlement of industrial relations disputes can be pursued through the Industrial Relations Court as an agency or forum that provides justice, while the judiciary shows the process of providing justice in order to enforce the law [12]. Based on Article 1 point 17 of Law Number 2 of 2004, the Industrial Relations Court is a special court established within the district court which has the authority to examine, hear and give decisions on industrial relations disputes. For the first time, an Industrial Relations Court is established in every Regency/City District Court located in each Provincial Capital whose jurisdiction covers the province concerned.

Meanwhile, settlement of disputes outside the court can be carried out through bipartite negotiations and tripartite negotiations (mediation, conciliation, arbitration).

\section{a) Bipartite Settlement Efforts}

Efforts must be made to resolve industrial relations disputes through deliberative bipartite negotiations to reach consensus. This means that before the disputing parties invite a third party to resolve the issue between them, they must first begin the stage of negotiating the parties, which is commonly referred to as the bipartite approach. Based on Article 1 point 10 of Law Number 2 of 2004, bipartite negotiations are negotiations between workers or laborers or trade unions or labor unions and employers to resolve industrial relations disputes. Dispute settlement through bipartite is regulated in the provisions of Article 3 to Article 7 of Law Number 2 of 2004.

If the bipartite negotiations are successful in reaching an agreement, a Collective Agreement is made that is binding and becomes law and must be implemented by the parties. This Collective Agreement must be registered by the parties who entered into the agreement at the Industrial Relations Court at the District Court in the territory of the parties to enter into a Collective Agreement. In the event that the Collective Agreement is not implemented by one of the parties, then the aggrieved party can file a request for execution at the Industrial Relations Court at the District Court in the area in the Collective Agreement area to be registered to receive an order of execution.

\section{b) Settlement Through Mediation}

Settlement of industrial relations disputes through mediation is carried out if no agreement is reached in bipartite negotiations. Efforts to settle industrial relations disputes through mediation are regulated in Article 8 through Article 16 of Law Number 2 of 2004. Based on 
Article 1 number 11 of Law Number 2 of 2004, mediation is the settlement of disputes over rights, disputes over interests, disputes over termination of employment, and disputes between trade unions / labor unions within one company only through deliberations brokered by one or more neutral mediators.

In the event that an agreement is reached for the settlement of industrial relations disputes through mediation, a Collective Agreement is drawn up which is signed by the parties and acknowledged by the mediator and is registered at the Industrial Relations Court at the District Court in the area of the parties to enter into a Collective Agreement to obtain a proof of registration deed.

\section{c) Settlement by Conciliation}

Industrial relations dispute settlement through conciliation is regulated in Article 17 to Article 28 of Law Number 2 of 2004. Based on Article 1 number 13 of Law Number 2 of 2004, Industrial Relations Conciliation, hereinafter referred to as conciliation, is the settlement of interests, disputes over termination of employment, or disputes between trade unions or labor unions within one company only through deliberation brokered by one or more neutral conciliators.

In the event that a settlement agreement is reached through conciliation, a Collective Agreement is drawn up which is signed by the parties known to the conciliator and is registered at the Industrial Relations Court at the District Court in the area of the parties to enter into a Collective Agreement.

\section{d) Settlement by Arbitration}

The institution authorized to referee disputes over interests and disputes between unions is the arbitrator. These arbitrators can be selected by the disputing parties from the list of arbitrators established by the minister. Settlement through arbitration is regulated in Article 29 to Article 54 of Law Number 2 of 2004. Based on Article 1 number 15 of Law Number 2 of 2004 , arbitration is the settlement of disputes of interest, and disputes between trade unions or labor unions in only one companies, outside the Industrial Relations Court through a written agreement from the disputing parties to submit dispute resolution to an arbitrator whose decision is binding on the parties and is final.

However, if the reconciliation effort fails, the arbitrator or panel of arbitrators continues the arbitration hearing. An arbitration award has legal force that binds the disputing parties and is a final and permanent award. The arbitration award is registered at the Industrial Relations Court at the District Court in the arbiter's territory to determine the decision. Industrial relations disputes that are currently or have been resolved through arbitration cannot be submitted to the Industrial Relations Court.

\section{Conclusion}

The conclusion of this study regarding the policy of laying off workers as a result of the Covid-19 Pandemic is that regarding the regulation of wages for workers who are sent home based on Point II of the Minister of Manpower Circular Number M/3/HK.04/III/2020 of 2020 concerning Protection of Workers / Laborers and Business Continuity in the Context of Prevention and Control of COVID-19 can be adjusted to the agreement between employers 
and workers, and regarding legal protection for workers who are laid off but do not receive a salary is regulated by Law Number 13 of 2003 concerning Manpower and Government Regulation Number 78 of 2015 concerning Wages, and it is also possible to settle industrial relations disputes through juridical (litigation) and non-juridical channels (non-litigation) through bipartite negotiations and tripartite negotiations (mediation, conciliation, arbitration) based on Law Number 2 of 2004 concerning the Industrial Relations Court.

\section{References}

[1] Mahfud MD: 2001, Dasar dan Struktur Ketatanegaraan Indonesia, Rieneke Cipta, Jakarta. pp. 127 (2001).

[2] Muladi: Hak Asasi Manusia, Refika Aditama, Bandung. Pp. 70 (2008).

[3] Joni Bambang: Hukum Ketenagakerjaan, Pustaka Setia Bandung, Bandung. pp. 269 (2013).

[4] Soeroso: Pengantar Ilmu Hukum, Cet. Ke-8, Penerbit Sinar Grafika, Jakarta. pp. 49 (2006)

[5] Satjipto Rahardjo: Ilmu Hukum, PT Citra Aditya Bakti, Bandung, pp. 54 (2006).

[6] Faisal Santiago: Pengantar Hukum Bisnis, Mitra Wacana Media, Jakarta, pp. 2 (2012).

[7] Harjono: Perlindungan Hukum Ketenagakerjaan, Raja Grafindo Persada, Jakarta. pp. 357 (2008).

[8] Satjipto Rahardjo: Sisi Sisi Lain dari Hukum Indonesia, Kompas, Jakarta. pp. 121 (2003).

[9] Joni Bambang: Hukum Ketenagakerjaan, Pustaka Setia Bandung, Bandung. pp. 269 (2013).

[10] Asri Wijayanti: Hukum Ketenagakerjaan Pasca Reformasi, Jakarta : Sinar Grafika. pp. 9 (2009).

[11] Asri Wijayanti: Hukum Ketenagakerjaan Pasca Reformasi, Jakarta : Sinar Grafika. pp. 10 (2009).

[12] Sjachran Basah: Eksistensi dan Tolak Ukur Badan Peradilan Administrasi di Indonesia, Alumni, Bandung. pp. 23 (1989). 